\title{
Wild and Cultivated Homoeologous Barley Chromosomes Can Associate and Recombine in Wheat in the Absence of the Ph1 Locus
}

\author{
María Carmen Calderón and Pilar Prieto *(D)
}

Citation: Calderón, M.C.; Prieto, P. Wild and Cultivated Homoeologous Barley Chromosomes Can Associate and Recombine in Wheat in the Absence of the Ph1 Locus. Agronomy 2021, 11, 147. https://doi.org/ 10.3390/agronomy11010147

Received: 23 December 2020 Accepted: 12 January 2021 Published: 14 January 2021

Publisher's Note: MDPI stays neutral with regard to jurisdictional clai$\mathrm{ms}$ in published maps and institutional affiliations.

Copyright: (C) 2021 by the authors. Licensee MDPI, Basel, Switzerland. This article is an open access article distributed under the terms and conditions of the Creative Commons Attribution (CC BY) license (https:// creativecommons.org/licenses/by/ $4.0 /)$.

\author{
Plant Breeding Department, Institute for Sustainable Agriculture, Agencia Estatal Consejo Superior de \\ Investigaciones Científicas (CSIC), Alameda del Obispo s/n, Apartado 4084, 14080 Córdoba, Spain; \\ carmencalderon@ias.csic.es \\ * Correspondence: pilar.prieto@ias.csic.es
}

\begin{abstract}
Bread wheat is an allohexaploid that behaves as a diploid during meiosis, the cell division process to produce the gametes occurring in organisms with sexual reproduction. Knowledge of the mechanisms implicated in meiosis can contribute to facilitating the transfer of desirable traits from related species into a crop like wheat in the framework of breeding. It is particularly interesting to shed light on the mechanisms controlling correct pairing between homologous (equivalent) chromosomes and recombination, even more in polyploid species. The Ph1 (Pairing homoeologous 1) locus is implicated in recombination. In this work, we aimed to study whether homoeologous (equivalent chromosomes from different genomes) Hordeum chilense (wild barley) and H. vulgare (cultivated barley) chromosomes can associate and recombine during meiosis in the wheat background in the absence of the Ph1 locus. For this, we have developed H. chilense and H. vulgare double monosomic addition lines for the same and for different homoeology group in wheat in the $p h 1 b$ mutant background. Using genomic in situ hybridization, we visualized the two (wild and cultivated) barley chromosomes during meiosis and we studied the processes of recognition, association, and recombination between homoeologous chromosomes in the absence of the Ph1 locus. Our results showed that the Ph1 locus does not prevent homoeologous chromosome pairing but it can regulate recombination.
\end{abstract}

Keywords: Triticum; Hordeum; homoeologous pairing; chromosome introgressions; meiosis; chromosome recognition; recombination; Ph1 locus

\section{Introduction}

Wheat is one of the oldest crops in the world. Its cultivation dates back 10,000 years ago during the Neolithic Revolution and it is considered one of the main reasons for which humans transformed from hunter-gatherer nomad to settled farmer [1]. Presently, wheat is the third most produced cereal in the world (734 million tons), only behind maize (1.1 million tons) and rice (782 million tons) (data taken from 2018; http: / / faostat3.fao.org/). Nevertheless, this production needs to be increased on account of the growing human population, which means that wheat crops need to be more productive and better adapted to specific agro-climatic conditions [2]. In this framework, plant breeders play an essential role to increase wheat quality and productivity by trying to understand gene functions and interactions, as well as exploiting the existing genetic variability in the development of new varieties better adapted to the environment. In fact, wide crossing is an important tool in plant breeding and sometimes the results are the starting point for new crops. Examples of new plant species developed in the Triticeae tribe are $\times$ Triticosecale, obtained after crossing wheat and rye, or $\times$ Tritordeum, an amphyploid between the wild barley $H$. chilense Roem. et Schult. and wheat [3,4]. Hence, in these cases, related species have been used by breeders as genetic donors for widening the genetic basis of wheat to get, for example, 
wheat cultivars better adapted to specific agro-climatic conditions, higher grain quality, or carrying resistance to diseases [5-8]. The use of relative species to transfer valuable genes into crops to improve grain nutritional quality and increase the total yield potential is based on interspecific hybridization of many cultivars with their wild relatives [9]. In the case of wheat, hybridization between wheat chromosomes and those from the wild related species produces only a low level of chromosome pairing and recombination, increasing the difficulty of introgressing desirable traits from the related species into it. Thus, going deeper into the knowledge of wheat genetics and its genome organization seems to be essential in the framework of plant breeding.

Bread wheat is an allopolyploid with three subgenomes (A, B, and D) which contain seven pairs of homologous (equivalent) chromosomes each one. Equivalent chromosomes from different subgenomes are named homoeologous chromosomes, which complicates the process of recognition and pairing during meiosis. Despite this genome complexity, hexaploid wheat behaves as a diploid during meiosis. This means that chromosomes associate regularly in pairs of homologues (equivalent chromosomes from the same subgenome), being homoeologous pairing prevented through the action of $\mathrm{Ph}$ (Pairing homoeologous) genes [10]. Among Ph genes, the Ph1 locus, located on the short arm of chromosome 5B, plays a major effect on chromosome associations during meiosis [11]. Other loci such as the Ph2 and the Ph3, located on the short arm of chromosomes 3D and $3 \mathrm{~A}$, respectively, have a weaker effect on meiosis than the Ph1 locus [12-14]. Due to its implication in meiosis, the Ph1 locus has been studied for decades and was initially described in charge of homologous chromosome pairing in bread wheat [11,15-17], although the molecular mechanisms behind these observations are still unclear. More recently, other functions of the Ph1 locus during meiosis have appeared. The Ph1 locus also suppresses recombination between homoeologous chromosomes [18-20] although it does not prevent chromosome associations between homoeologues [21]. It is clear that the precise control of chromosome pairing is crucial for conferring meiotic regularity, and hence reproductive stability in allopolyploids [22].

Several studies have explored chromatin arrangements in interphase nuclei, chromosome interactions, and movements during meiotic prophase I, and mechanisms that ensure correct segregation of chromosomes during anaphase. These studies have shed some light on chromosome dynamics in Arabidopsis thaliana as well as in plants with large and complex genomes such as wheat and maize [23]. In wheat, at the onset of meiosis, homologous chromosomes are sorted in pairs and are intimately associated along their lengths while a proteinaceous structure, the synaptonemal complex (SC), is assembled between them. Despite all the existing information regarding these processes, how homologues find each other to associate correctly in pairs is one of the least understood meiotic events [24-26]. In wheat, when a chromosome recognizes its homologue and not another chromosome, a localized conformational change in adjacent chromatin is triggered in both partners, facilitating recognition and pairing of homologous versus homoeologous chromosomes, this process also being under the effect of the Ph1 locus [14,27]. Thus, the Ph1 locus has a big influence on fertility but in contrast, has a negative effect for plant breeding purposes since it avoids pairing and recombination between wheat chromosomes and those from related species. Therefore, the study of chromosome associations during meiosis in wheat is necessary and can contribute to developing valuable tools in the framework of breeding.

The development of alien chromosome additions has an important utility not only for breeding but also for plant genetic studies. The availability of chromosome introgressions into a crop like wheat make these lines powerful tools for fundamental research, contributing, for example, to elucidating the processes of homoeologous recombination, distribution of chromosome-specific markers, and repetitive DNA sequences, and regulation of heterologous gene expression [28]. Sets of both cultivated (H. vulgare) and wild (H. chilense) barley addition lines in a hexaploid wheat background were developed several decades ago [29-31] and still currently have an enormous potential in plant meiosis studies. These lines allow the targeting of one specific pair of chromosomes or just a chromosome section 
within the wheat background using genomic in situ hybridization (GISH), and as a result, rearrangements and associations in a pair of homologues can be studied individually [32]

In this study, we developed double monosomic addition lines of cultivated and wild barley, $H$. vulgare and $H$. chilense, respectively, in the wheat $p h 1 b$ mutant background for the same and for different homoeology group with the aim of going deeper into the knowledge of chromosome associations during meiosis. These double monosomic addition lines allow the visualization of chromosomes from two different barley species in wheat in the $p h 1 b$ mutant background and analyze whether the $P h 1$ locus might play a role in chromosome recognition/pairing at early meiosis in the absence of homologues. Results showed that the $P h 1$ locus does not impede homoeologous recognition and pairing between $H$. chilense and $H$. vulgare chromosomes during meiosis but recombination, which only occurs in the absence of the $P h 1$ locus.

\section{Materials and Methods}

\subsection{Plant Material}

In this work we used $H$. vulgare and $H$. chilense monosomic addition lines in bread wheat (Triticum aestioum cv. Chinese Spring) in the ph1b mutant background carrying one $H$. vulgare or one $H$. chilense chromosome (AABBDD ph1bph $1 b+\mathrm{H}^{\mathrm{v}}$ and AABBDD $p h 1 b p h 1 b+\mathrm{H}^{\mathrm{ch}}$, respectively), which were developed previously in our lab [33]. These lines were allowed to self-pollinate to obtain $H$. chilense and $H$. vulgare disomic addition lines in the wheat ph1b mutant background to be used as parental lines with the aim of developing $H$. chilense and $H$. vulgare double monosomic addition lines in the wheat ph $1 b$ mutant background. Hordeum chilense and H. vulgare double monosomic addition lines in the presence of the Ph1 locus were also used [21].

Seeds were germinated on wet filter paper in the dark for 5 days at $4{ }^{\circ} \mathrm{C}$, followed by a period of $24 \mathrm{~h}$ at $25^{\circ} \mathrm{C}$. emerging seedling roots were cut, incubated during $4 \mathrm{~h}$ in $0.05 \%$ w/v colchicine at $25^{\circ} \mathrm{C}$, fixed in Carnoy's solution (three parts $100 \%$ ethanol plus, one part glacial acetic acid) and stored at $4{ }^{\circ} \mathrm{C}$ until their use. Plants were then grown in the greenhouse at $26^{\circ} \mathrm{C}$ during the day and $18^{\circ} \mathrm{C}$ during the night (16 h photoperiod). Immature spikes were collected and were also preserved in Carnoy's solution and used to characterise chromosome pairing at meiosis I.

\subsection{DNA Characterization}

Genomic DNA was extracted from frozen seedling leaves following the protocol described by [34] with some modifications [35]. The absence of the Ph1 locus in the lines used in this work was verified using the ABC920 SCAR marker [36]. The presence of each Hordeum sp. chromosome was confirmed by both PCR $[37,38]$ and in italics hybridization.

\subsection{Fluorescence In Situ Hybridization}

Associations between $H$. vulgare and $H$. chilense chromosomes in wheat in the ph1b mutant background were studied using fluorescence genomic in situ hybridization (GISH) [39]. Root tips and spikes in meiosis were collected and pre-treated as described previously [21]. Chromosome spreads were obtained from both root tips and anthers in meiosis as described [21]. Genomic DNA extracted from $H$. vulgare and $H$. chilense seedling leaves was used as probes for GISH experiments. Hordeum vulgare and H. chilense genomic DNA were labeled by nick translation with biotin-11 (Boehringer Mannheim Biochemicals, Germany) and digoxigenin-11-dUTP (Roche Applied Science, Indianapolis, IN, USA), respectively. The in situ hybridization protocol was performed according to [21].

\subsection{Fluorescence Microscopy and Image Processing}

Hybridization signals were visualized using a Nikon Eclipse 80i epifluorescence microscope. Images were captured with a Nikon CCD camera using the Nikon 3.0 software (Nikon Instruments Europe BV, Amstelveen, The Netherlands) and processed with Photoshop 11.0.2 software (Adobe Systems Inc., San Jose, CA, USA). 


\section{Results}

3.1. Development of Double Monosomic H. vulgare-H. chilense Addition Lines in Wheat in the ph1b Mutant Background

With the aim of obtaining double monosomic $H$. chilense- $H$. vulgare addition lines in wheat in the $p h 1 b$ mutant background, we cultivated 50 monosomic $H$. chilense and $H$. vulgare addition lines for chromosomes $5 \mathrm{H}^{\mathrm{ch}}, 7 \mathrm{H}^{\mathrm{ch}}$, and $7 \mathrm{H}^{\mathrm{v}}$, which were previously developed in our lab in the absence of the Ph1 locus [35]. These monosomic addition lines were self-pollinated in order to identify disomic addition lines for each Hordeum chromosome in the segregation population in the wheat $p h 1 b$ mutant background. F2 seeds were germinated and plants were screened by PCR using molecular markers to confirm the presence of the $H$. chilense or $H$. vulgare chromosomes and the $p h 1 b$ deletion. Those plants carrying either the $H$. chilense or $H$. vulgare chromosomes in the absence of the Ph1 locus were selected and analyzed by GISH to identify disomic addition lines for each $5 \mathrm{H}^{\mathrm{ch}}, 7 \mathrm{H}^{\mathrm{ch}}$, and $7 \mathrm{H}^{\mathrm{v}}$ chromosomes. GISH analysis was required to distinguish among the positive plants for a specific chromosome, those carrying two copies of the desirable $H$. chilense or $H$. vulgare chromosome. Only 8,5 , and 5 wheat plants were identified carrying two copies of each $5 \mathrm{H}^{\mathrm{ch}}, 7 \mathrm{H}^{\mathrm{ch}}$, and $7 \mathrm{H}^{\mathrm{v}}$, respectively, in the $p h 1 b$ mutant background (Table 1). After in situ hybridization experiments, these $5 \mathrm{H}^{\mathrm{ch}}, 7 \mathrm{H}^{\mathrm{ch}}$, and $7 \mathrm{H}^{\mathrm{v}}$ disomic addition lines in the $p h 1$ mutant background were cultivated until grain was obtained. Then, seeds were germinated, and plants were cultivated and used as parental lines for genetic crosses to generate double monosomic $H$. chilense- $H$. vulgare addition lines in wheat in the $p h 1 b$ mutant background. A summary of the process and the number of plants obtained is shown in detail in Figure 1 and Table 1.

Table 1. (a) Plants used for genetic crosses to develop wheat lines carrying a Hordeum disomic addition in the $p h 1 b$ mutant background. (b) Plants obtained after genetic crosses between disomic addition lines.

(a)

\begin{tabular}{|c|c|c|c|c|c|}
\hline \multicolumn{3}{|c|}{ parental lines $p h 1 b p h 1 b$} & \multicolumn{3}{|c|}{ self-pollinated progeny $p h 1 b p h 1 b$} \\
\hline $\begin{array}{c}7 \mathrm{H}^{\mathrm{v}} \\
\text { monosomic } \\
\text { addition line }\end{array}$ & $\begin{array}{l}5 \mathrm{H}^{\mathrm{ch}} \\
\text { monosomic } \\
\text { addition line }\end{array}$ & $\begin{array}{l}\text { 7H } \\
\text { monosomic } \\
\text { addition line }\end{array}$ & $\begin{array}{c}7 \mathrm{H}^{\mathrm{v}} 7 \mathrm{H}^{\mathrm{v}} \\
\text { disomic } \\
\text { addition line }\end{array}$ & $\begin{array}{c}5 \mathrm{H}^{\mathrm{ch}} 5 \mathrm{H}^{\mathrm{ch}} \\
\text { disomic } \\
\text { addition line }\end{array}$ & $\begin{array}{c}7 \mathrm{H}^{\mathrm{ch}} 7 \mathrm{H}^{\mathrm{ch}} \\
\text { disomic } \\
\text { addition line }\end{array}$ \\
\hline 50 & 50 & 50 & 5 & 8 & 5 \\
\hline \multicolumn{6}{|l|}{ (b) } \\
\hline \multicolumn{2}{|c|}{ F1 progeny ph1bph1b } & \multicolumn{4}{|c|}{ F2 progeny ph1bph1b } \\
\hline $\begin{array}{l}7 \mathrm{H}^{\mathrm{v}} \mathrm{L} 5 \mathrm{H}^{\mathrm{ch}} \\
\text { double } \\
\text { monosomic } \\
\text { addition line }\end{array}$ & $\begin{array}{l}7 \mathrm{H}^{\mathrm{v}} \mathrm{L} \mathrm{H}^{\mathrm{ch}} \\
\text { double } \\
\text { monosomic } \\
\text { addition line }\end{array}$ & $\begin{array}{l}7 \mathrm{H}^{\mathrm{V}} \mathrm{L} 5 \mathrm{H}^{\mathrm{ch}} \\
\text { double } \\
\text { monosomic } \\
\text { addition line }\end{array}$ & $\begin{array}{l}7 \mathrm{H}^{\mathrm{v}} \mathrm{L} 7 \mathrm{H}^{\mathrm{ch}} \\
\text { double } \\
\text { monosomic } \\
\text { addition line }\end{array}$ & $\begin{array}{c}7 \mathrm{H}^{\mathrm{v}} \mathrm{L} \\
\text { monosomic } \\
\text { addition line }\end{array}$ & $\begin{array}{l}7 \mathrm{H}^{\mathrm{v}} \mathrm{L} 5 \mathrm{H}^{\mathrm{ch}} \\
\text { aneusomaty }\end{array}$ \\
\hline 26 & 20 & 5 & 3 & 1 & 1 \\
\hline
\end{tabular}


(a)

$$
\begin{aligned}
& 7 \mathrm{H}^{\mathrm{v}} \text { monosomic addition line in bread wheat } p h 1 b \text { mutant } \\
& \text { (7AA7BB7DD } p h 1 b p h 1 b+1 \times 7 \mathrm{H}^{\mathrm{v}} \text { ) } \\
& 2 \mathrm{n}=14 \mathrm{~A}+14 \mathrm{~B}+14 \mathrm{D}+1 \mathrm{x} 7 \mathrm{H}^{\mathrm{v}}=43 \\
& \otimes \\
& \text { (7AA7BB7DD } p h 1 p h 1+\text { pair } 7 \mathrm{H}^{v} \text { ) } \\
& 2 \mathrm{n}=14 \mathrm{~A}+14 \mathrm{~B}+14 \mathrm{D}+2 \times 7 \mathrm{H}^{\mathrm{v}}=44
\end{aligned}
$$

$7 \mathrm{H}^{\text {ch }}$ monosomic addition line in bread wheat phlb mutant (7AA7BB7DD phlbphlb $+1 \times 7 \mathrm{H}^{\mathrm{ch}}$ ) $2 \mathrm{n}=14 \mathrm{~A}+14 \mathrm{~B}+14 \mathrm{D}+1 \times 7 \mathrm{H}^{\mathrm{ch}}=43$

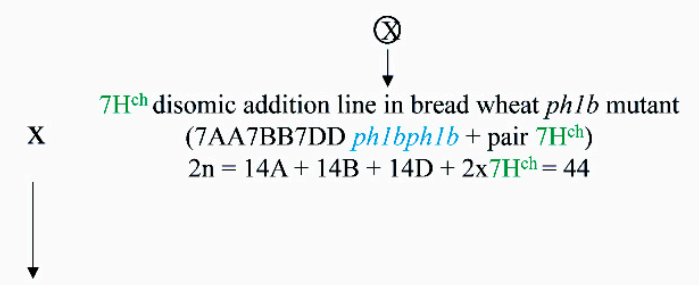

F1

$7 \mathrm{H}^{\mathrm{v}} \mathrm{L} 7 \mathrm{H}^{\mathrm{ch}}$ double monosomic addition line in bread wheat $p h l b$ mutant (7AA7BB7DD $p h l b p h l b+1 \times 7 \mathrm{H}^{\mathrm{v}} \mathrm{L}+1 \times 7 \mathrm{H}^{\mathrm{ch}}$ ) $2 \mathrm{n}=14 \mathrm{~A}+14 \mathrm{~B}+14 \mathrm{D}+1 \times 7 \mathrm{H}^{\mathrm{v}} \mathrm{L}+1 \times 7 \mathrm{H}^{\mathrm{ch}}=44$

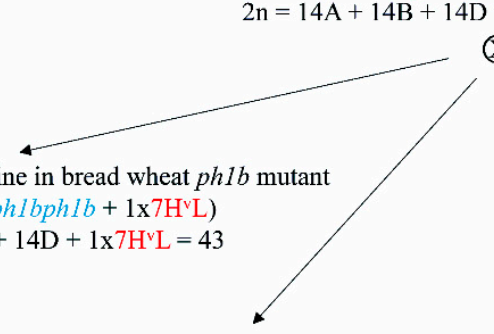

$7 \mathrm{H}^{\mathrm{ch}}$ monosomic addition line in bread wheat phlb mutant (7AA7BB7DD $\left.p h l b p h l b+1 \times 7 \mathrm{H}^{\mathrm{ch}}\right)$ $2 \mathrm{n}=14 \mathrm{~A}+14 \mathrm{~B}+14 \mathrm{D}+1 \times 7 \mathrm{H}^{\mathrm{ch}}=43$
Q)

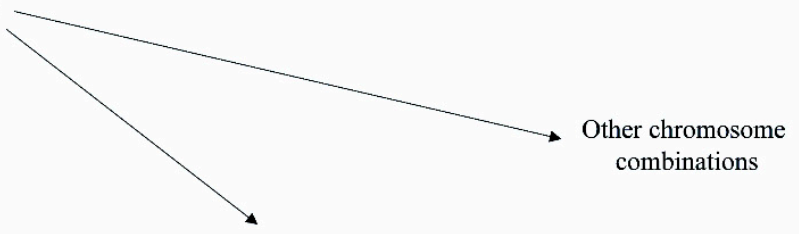

$7 \mathrm{H}^{\mathrm{v}} \mathrm{L} 7 \mathrm{H}^{\text {ch }}$ double monosomic addition line in bread wheat $p h 1 b$ mutant (7AA7BB7DD $p h 1 b p h 1 b+1 \times 7 \mathrm{H}^{2} \mathrm{~L}+1 \times 7 \mathrm{H}^{\text {ch }}$ ) $2 \mathrm{n}=14 \mathrm{~A}+14 \mathrm{~B}+14 \mathrm{D}+1 \times 7 \mathrm{H}^{\mathrm{v}} \mathrm{L}+1 \times 7 \mathrm{H}^{\mathrm{ch}}=44$

(b)

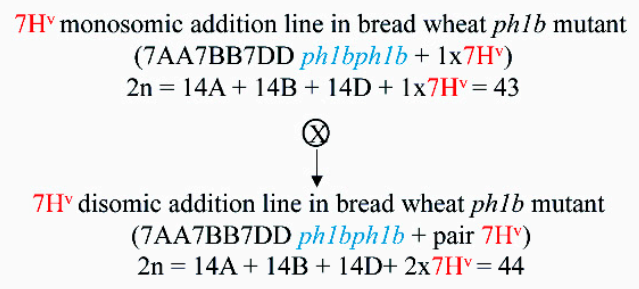
(7AA7BB7DD $p h 1 b p h 1 b+$ pair $7 \mathrm{H}^{\mathrm{v}}$ ) $2 \mathrm{n}=14 \mathrm{~A}+14 \mathrm{~B}+14 \mathrm{D}+2 \mathrm{x} 7 \mathrm{H}^{\mathrm{v}}=44$

$5 \mathrm{H}^{\text {ch }}$ monosomic addition line in bread wheat $p h l b$ mutant

(7AA7BB7DD phlbphlb $+1 \times 5 \mathrm{H}^{\mathrm{ch}}$ )

$2 \mathrm{n}=14 \mathrm{~A}+14 \mathrm{~B}+14 \mathrm{D}+1 \times 5 \mathrm{H}^{\mathrm{ch}}=43$

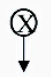

$5 \mathrm{H}^{\text {ch }}$ disomic addition line in bread wheat $p h 1 b$ mutant

(7AA7BB7DD $p h 1 b p h 1 b+$ pair $5 \mathrm{H}^{\mathrm{ch}}$ )

$2 \mathrm{n}=14 \mathrm{~A}+14 \mathrm{~B}+14 \mathrm{D}+2 \times 5 \mathrm{H}^{\mathrm{ch}}=44$

F1

$7 \mathrm{H}^{\vee} \mathrm{L} 5 \mathrm{H}^{\text {ch }}$ double monosomic addition line in bread wheat $p h 1 b$ mutant (7AA7BB7DD $p h 1 b p h 1 b+1 \times 7 \mathrm{H}^{v} \mathrm{~L}+1 \times 5 \mathrm{H}^{\text {ch }}$ ) $2 \mathrm{n}=14 \mathrm{~A}+14 \mathrm{~B}+14 \mathrm{D}+1 \times 7 \mathrm{H}^{\mathrm{V}} \mathrm{L}+1 \times 5 \mathrm{H}^{\mathrm{ch}}=44$

$7 \mathrm{H}^{\mathrm{v}} \mathrm{L}$ monosomic addition line in bread wheat $p h 1 b$ mutant (7AA7BB7DD $\left.p h 1 b p h 1 b+1 \times 7 \mathrm{H}^{\mathrm{L}} \mathrm{L}\right)$ $2 n=14 A+14 B+14 D+1 \times 7 H^{v} L=43$

$5 \mathrm{H}^{\mathrm{ch}}$ monosomic addition line in bread wheat phlb mutant (7AA7BB7DD $p h 1 b p h 1 b+1 \times 5 \mathrm{H}^{\mathrm{ch}}$ )
Q

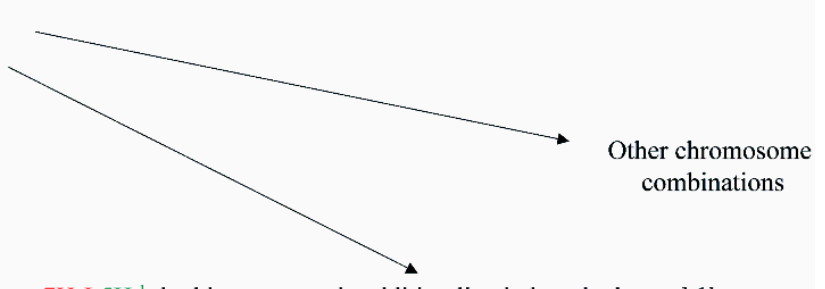

$7 \mathrm{H}^{v} \mathrm{~L} 5 \mathrm{H}^{\text {ch }}$ double monosomic addition line in bread wheat $p h 1 b$ mutant (7AA7BB7DD ph1bph1b $+1 \times 7 \mathrm{H}^{\mathrm{v}} \mathrm{L}+1 \times 5 \mathrm{H}^{\mathrm{ch}}$ ) $2 n=14 A+14 B+14 D+1 \times 7 H^{v} L+1 \times 5 H^{c h}=44$

Figure 1. Development of double monosomic $H$. vulgare and $H$. chilense addition lines in wheat in the ph1b mutant background. (a) Diagram of genetic crosses developed to obtain the $7 \mathrm{H}^{\mathrm{v}} \mathrm{L} 7 \mathrm{H}^{\text {ch }}$ double monosomic addition line in wheat in the ph1b mutant background. (b) Diagram of genetic crosses developed to obtain the $7 \mathrm{H}^{\mathrm{v}} \mathrm{L}^{\mathrm{H}} \mathrm{H}^{\mathrm{ch}}$ double monosomic addition line in wheat in the ph1b mutant background.

Only 20 grains were obtained from the genetic crosses between the $7 \mathrm{H}^{\mathrm{v}}$ and the $7 \mathrm{H}^{\text {ch }}$ disomic addition lines in the absence of the $P h 1$ locus. Similarly, only 26 grains were 
obtained from the genetic crosses between the $7 \mathrm{H}^{\mathrm{v}}$ and the $5 \mathrm{H}^{\text {ch }}$ disomic addition lines in wheat in the ph1b mutant background (Table 1). All these grains were germinated, and plants were screened by PCR using molecular markers to confirm simultaneously the presence of one $H$. chilense chromosome, one $H$. vulgare chromosome, and the $p h 1 b$ deletion. Unfortunately, it was not possible to detect any $H$. chilense and H. vulgare double monosomic addition lines carrying the whole chromosome $7 \mathrm{H}^{\mathrm{v}}$. Chromosome $7 \mathrm{H}^{\mathrm{v}}$ was always identified as a telosomic $7 \mathrm{H}^{\mathrm{v}} \mathrm{L}$ chromosome. Thus, we only obtained $\mathrm{H}$. chilense and $H$. vulgare double monosomic addition lines carrying the whole $5 \mathrm{H}^{\text {ch }}$ or $7 \mathrm{H}^{\text {ch }} H$. chilense chromosome and the telosomic $7 \mathrm{H}^{\mathrm{v}} \mathrm{L}$ chromosome. This means that chromosome associations between $H$. chilense and $H$. vulgare chromosomes were only possible to study in the long chromosome arm of both Hordeum chromosomes in the absence of the Ph1 locus. These double monosomic wild and barley addition lines in wheat in the ph1b mutant background were selected to study the effect of the Ph1 locus on chromosome associations. Thus, plant lines were cultivated until meiosis to analyze $H$. chilense and $H$. vulgare chromosome associations for both the same homoeology group $\left(7 \mathrm{H}^{\text {ch }} 7 \mathrm{H}^{\mathrm{v}} \mathrm{L}\right)$ and for different homoeology groups $\left(5 \mathrm{H}^{\mathrm{ch}} 7 \mathrm{H}^{\mathrm{v}} \mathrm{L}\right)$ in the wheat $p h 1 b$ mutant background. Only the first spike was taken from each plant for meiosis scoring, leaving the rest of the spikes to develop until maturity to obtain F2 seeds. Spikes entering meiosis were isolated and chromosome spreads from anthers were used for GISH experiments to study chromosome associations between homoeologous chromosomes in the absence of the Ph1 locus.

3.2. Non-Homologous Chromosome Associations between H. vulgare and H. chilense Are Allowed during Early Meiosis in Wheat in the ph1b Mutant Background

Chromosome associations between $H$. vulgare and $H$. chilense chromosomes for the same $\left(7 \mathrm{H}^{\mathrm{v}} \mathrm{L}\right.$ and $\left.7 \mathrm{H}^{\text {ch }}\right)$ and for different $\left(7 \mathrm{H}^{\mathrm{v}} \mathrm{L}\right.$ and $\left.5 \mathrm{H}^{\mathrm{ch}}\right)$ homoeology groups were studied in pachytene in double $H$. chilense- $H$. vulgare monosomic addition lines in wheat in the absence of the $P h 1$ locus. In addition, equivalent $H$. chilense and $H$. vulgare double monosomic addition lines, for the same and for different homoeology groups in the presence of the Ph1 locus, were also grown. Hordeum chilense and H. vulgare chromosomes were visualized during meiosis by GISH to accurately assess the effect of the $P h 1$ locus on chromosome associations. It is worth saying that $H$. vulgare chromosome $7 \mathrm{H}^{\mathrm{v}}$ was complete in these wheat lines carrying the Ph1 locus.

In situ hybridization experiments in meiosis were developed in more than 250 pollen mother cells (PMCs) of each genomic combination $\left(7 \mathrm{H}^{\mathrm{v}} \mathrm{L} 7 \mathrm{H}^{\mathrm{ch}}\right.$ and $\left.7 \mathrm{H}^{\mathrm{v}} \mathrm{L} 5 \mathrm{H}^{\mathrm{ch}}\right)$ in the $p h 1 b$ mutant and results were visualized in prophase I of meiosis (Figure 2). GISH experiments showed that $H$. vulgare and $H$. chilense homoeologous chromosomes $\left(7 \mathrm{H}^{\mathrm{v}} \mathrm{L} 7 \mathrm{H}^{\mathrm{ch}}\right)$ were always fully-associated in pairs by the long chromosome arms during pachytene in both wheat backgrounds, in the presence and in the absence of the Ph1 locus (Figure 2a,c). In contrast, non-homoeologous Hordeum chromosomes $7 \mathrm{H}^{\mathrm{v}} \mathrm{L}$ and $5 \mathrm{H}^{\mathrm{ch}}$ were not observed associated at any time in the presence of the $P h 1$ locus (Figure $2 b$ ), confirming previous results from our group [21]. However, we visualized some minor chromosome associations between $7 \mathrm{H}^{\mathrm{v}} \mathrm{L}$ and $5 \mathrm{H}^{\mathrm{ch}}$ non-homoeologous chromosomes in $10.89 \%$ of the PMCs during pachytene in the $p h 1 b$ mutant background (Figure 2d), involving a small chromosome portion of both non-homoeologues. Our observations showed that homoeologous barley chromosomes could associate both in the presence and in the absence of the Ph1 locus. Chromosome pairing between non-homoeologous chromosomes from two different Hordeum species can also be allowed in the absence of the Ph1 locus. Thus, homoeologous barley chromosomes can recognize each other by equivalent chromosome regions and trigger a chromatin conformational change independently of the Ph1 locus (Figure 2a,c). 


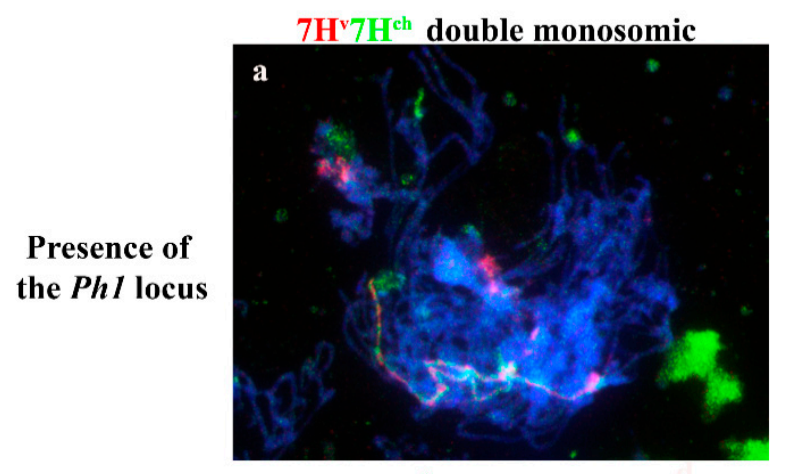

$7 \mathrm{H}^{\mathrm{v}} \mathrm{L} 7 \mathrm{H}^{\mathrm{ch}}$ double monosomic

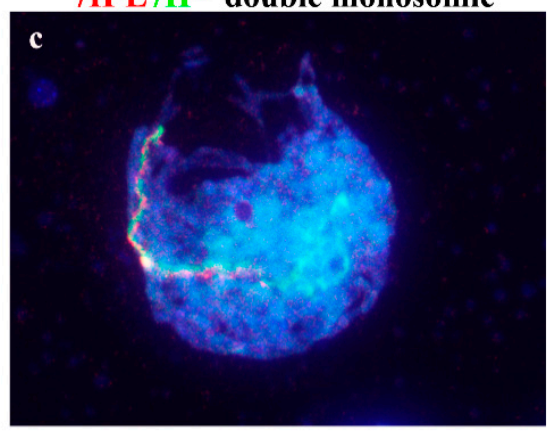

$7 \mathrm{H}^{\mathrm{v}} 5 \mathrm{H}^{\mathrm{ch}}$ double monosomic

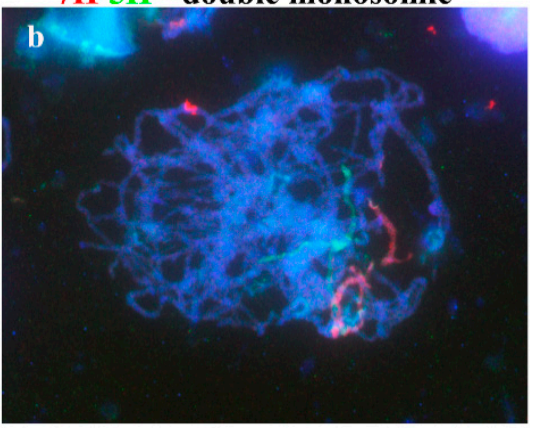

$7 \mathrm{H}^{\mathrm{v}} \mathrm{L} 5 \mathrm{H}^{\text {ch }}$ double monosomic

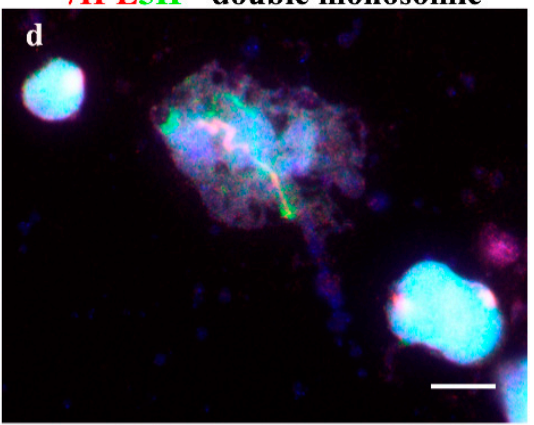

Figure 2. Analysis of pairing between homoeologous and non-homoeologous barley chromosomes during early meiosis in the presence and in the absence of the Ph1 locus. Hordeum vulgare (red) and $H$. chilense (green) chromosomes. DNA was counterstained with DAPI (blue). (a) $7 \mathrm{H}^{\mathrm{v}} 7 \mathrm{H}^{\mathrm{ch}}$ double monosomic addition line showing both barley chromosomes associated at early pachytene in the presence of the Ph1 locus. (b) Non-homoeologous $7 \mathrm{H}^{\mathrm{v}}$ and $5 \mathrm{H}^{\mathrm{ch}}$ did not associated in the presence of the $\mathrm{Ph} 1$ locus. (c) $7 \mathrm{H}^{\mathrm{v}} \mathrm{L} 7 \mathrm{H}^{\mathrm{ch}}$ double monosomic addition mutant line showing both barley chromosomes associated by the long chromosome arm at early pachytene in the $p h 1 b$ mutant background. (d) $7 \mathrm{H}^{\mathrm{v}} \mathrm{L} 5 \mathrm{H}^{\text {ch }}$ double monosomic addition mutant line showing both barley chromosomes partially associated at early pachytene in the ph1b mutant background. Bar: $10 \mu \mathrm{m}$.

3.3. Recombination Can Occur Indistinctly between Wild Barley, Cultivated Barley, and Wheat Chromosomes in the Absence of the Ph1 Locus

Taking into account that homoeologous and non-homoeologous chromosome associations between $H$ chilense and $H$. vulgare chromosomes did occur in wheat, we focused on studying whether or not these chromosome associations could allow overcrossing and recombination events in the absence of the $P h 1$ locus. Thus, we analyzed chromosome associations in pollen mother cells (PMCs) in metaphase I from $H$. vulgare and $H$. chilense double monosomic addition lines for the same and different homoeologous group in wheat in the ph $1 b$ mutant background. $7 \mathrm{H}^{\mathrm{v}} 7 \mathrm{H}^{\mathrm{ch}}$ and $7 \mathrm{H}^{\mathrm{v}} 5 \mathrm{H}^{\mathrm{ch}}$ double monosomic additions in wheat in the presence of the Ph1 locus were used as control. Cultivated and wild barley chromosomes remained always as univalent in GISH experiments in metaphase I in the presence of the Ph1 locus, in both situations (same and different homoeologous group, Figure $3 a, b)$, as was previously described [21]. In contrast, several types of associations between $H$. vulgare and $H$. chilense chromosomes were detected in the absence of the Ph1 locus for both the same and different homoeologous groups (Figure 3c-1). Associations in metaphase I between $H$. vulgare and $H$. chilense, $H$. chilense and wheat, and $H$. vulgare and wheat chromosomes were observed (Figure $3 \mathrm{c}-\mathrm{h}$ ) in both $7 \mathrm{H}^{\mathrm{v}} \mathrm{L} 7 \mathrm{H}^{\mathrm{ch}}$ and $7 \mathrm{H}^{\mathrm{v}} \mathrm{L}^{\mathrm{c}} \mathrm{H}^{\mathrm{ch}}$ double monosomic addition lines in the ph1b mutant background, as well as double $H$. chilense-wheat and $H$. vulgare-wheat associations (Figure 3i,j) and tripartite $H$. vulgare- $H$. chilense-wheat associations (Figure 3k,1). The most frequent association in both wheat lines carrying homoeologous $\left(7 \mathrm{H}^{\mathrm{v}} \mathrm{L} 7 \mathrm{H}^{\mathrm{ch}}\right)$ and non-homoeologous chromosomes $\left(7 \mathrm{H}^{\mathrm{v}} \mathrm{L}^{\mathrm{H}} \mathrm{H}^{\mathrm{ch}}\right)$ occurred between $H$. vulgare and $H$. chilense chromosomes (20.85\% and $7.26 \%$, respectively, 
Table 2). Our results showed that recombination was, as expected, more frequent between homoeologous chromosomes than non-homoeologous chromosomes, supporting chromosome associations observed during pachytene between $7 \mathrm{H}^{\mathrm{v}} \mathrm{L}$ and $7 \mathrm{H}^{\text {ch }}$ chromosomes, which were also more frequent than associations occurring between $7 \mathrm{H}^{\mathrm{v}} \mathrm{L}$ and $5 \mathrm{H}^{\text {ch }}$ chromosomes. The H. vulgare- $H$. chilense-wheat tripartite chromosomes association was the least frequent in both lines carrying $7 \mathrm{H}^{\mathrm{v}} 7 \mathrm{LH}^{\mathrm{ch}}$ and $7 \mathrm{H}^{\mathrm{v}} \mathrm{L}^{\mathrm{H}} \mathrm{H}^{\mathrm{ch}}$ chromosomes in the ph1b background $(0.47 \%$ and $0.33 \%$, respectively) (Table 2$)$. These observations suggested that, although homoeologous chromosomes $7 \mathrm{H}^{\mathrm{v}} \mathrm{L}$ and $7 \mathrm{H}^{\mathrm{ch}}$ can associate in pairs during pachytene both in the presence and in the absence of the Ph1 locus, recombination can only occur in the absence of the Ph1 locus. In addition, although chromosome associations between non-homoeologues can occur in equivalent chromosome regions, recombination events were rare between non-homoeologues. Moreover, chromosome associations and recombination events between wild or cultivated barley chromosomes and wheat were less frequent, suggesting that chromosome associations might depend on genome homology, as $H$. chilense and $H$. vulgare species are phylogenetically closer between them than to wheat. The absence of homologues in the case of Hordeum chromosomes might also contribute to increase chromosome associations between both wild and cultivated barley chromosomes, which did not occur in the case of wheat chromosomes where the two homologues for all wheat chromosomes were always present. In summary, our observations suggested that the Ph1 locus cannot suppress homoeologous chromosome associations in wheat but recombination, because no recombination events were detected between homoeologous $H$. chilense and H. vulgare chromosomes in any case in the presence of the Ph1 locus.

Table 2. Frequency of pairing between $H$. vulgare, $H$. chilense, and wheat chromosomes in metaphase I in double monosomic addition lines in the presence and in the absence of the $P h 1$ locus.

\begin{tabular}{|c|c|c|c|c|c|c|c|c|}
\hline \multirow[b]{2}{*}{$\begin{array}{l}\text { Wheat } \\
\text { Line }\end{array}$} & \multirow{2}{*}{$\begin{array}{l}\text { Number of } \\
\text { Plants } \\
\text { Analyzed } \\
\text { in } \\
\text { Metaphase }\end{array}$} & \multirow{2}{*}{$\begin{array}{l}\text { Number of } \\
\text { PMCs } \\
\text { Scored in } \\
\text { Metaphase }\end{array}$} & \multicolumn{6}{|c|}{$\begin{array}{c}\text { Number (and Frequency) of PMCs Carrying Chromosome Associations Scored in } \\
\text { Metaphase I }\end{array}$} \\
\hline & & & $\begin{array}{l}\mathrm{H}^{\mathrm{v}}-\mathrm{H}^{\mathrm{ch}} \\
\text { Pairing }\end{array}$ & $\begin{array}{l}\mathrm{H}^{\mathrm{ch}} \text {-Wheat } \\
\text { Pairing }\end{array}$ & $\begin{array}{l}\mathrm{H}^{\mathrm{v}}-\text { Wheat } \\
\text { Pairing }\end{array}$ & $\begin{array}{c}\mathrm{H}^{\mathrm{ch}} \text {-Wheat } \\
\text { andH } \mathrm{H}^{\mathrm{v}}- \\
\text { Wheat } \\
\text { Pairing }\end{array}$ & $\begin{array}{l}\mathrm{H}^{\mathrm{v}}-\mathrm{H}^{\mathrm{ch}}- \\
\text { Wheat } \\
\text { Pairing }\end{array}$ & $\begin{array}{l}\text { Total } \\
\text { Pairing }\end{array}$ \\
\hline $\begin{array}{l}7 \mathrm{H}^{\mathrm{v}} 7 \mathrm{H}^{\mathrm{ch}} \\
\text { double } \\
\text { monosomic } \\
\text { Ph1Ph1 }\end{array}$ & 2 & 107 & 0 & 0 & 0 & 0 & 0 & 0 \\
\hline $\begin{array}{l}7 \mathrm{H}^{\mathrm{v}} 5 \mathrm{H}^{\mathrm{ch}} \\
\text { double } \\
\text { monosomic } \\
\text { Ph1Ph1 }\end{array}$ & 2 & 159 & 0 & 0 & 0 & 0 & 0 & 0 \\
\hline $\begin{array}{l}7 \mathrm{H}^{\mathrm{v}} \mathrm{L} 7 \mathrm{H}^{\mathrm{ch}} \\
\text { double } \\
\text { monosomic } \\
\text { ph1bph1b }\end{array}$ & 2 & 211 & $44(20.85 \%)$ & $18(8.53 \%)$ & $18(8.53 \%)$ & $4(1.89 \%)$ & $1(0.47 \%)$ & $85(40.27 \%)$ \\
\hline $\begin{array}{l}7 \mathrm{H}^{\mathrm{v}} \mathrm{L} 5 \mathrm{H}^{\mathrm{ch}} \\
\text { double } \\
\text { monosomic } \\
\text { ph1bph1b }\end{array}$ & 2 & 303 & $22(7.26 \%)$ & $7(2.31 \%)$ & $8(2.64 \%)$ & $2(0.66 \%)$ & $1(0.33 \%)$ & $40(13.20 \%)$ \\
\hline
\end{tabular}


Presence of the $P h 1$ locus
$7 \mathrm{H}^{\mathrm{v}} 7 \mathrm{H}^{\mathrm{ch}}$

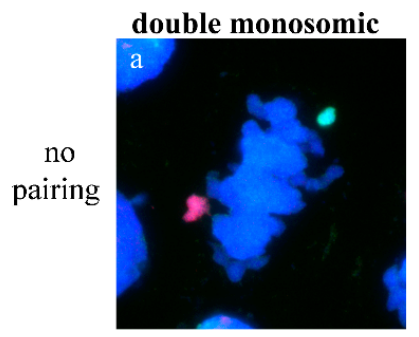

$7 \mathrm{H}^{\mathrm{v}} 5 \mathrm{H}^{\mathrm{ch}}$

double monosomic

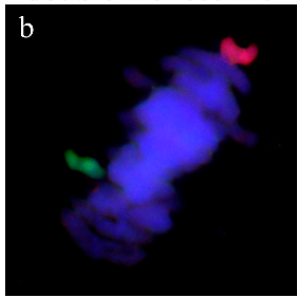

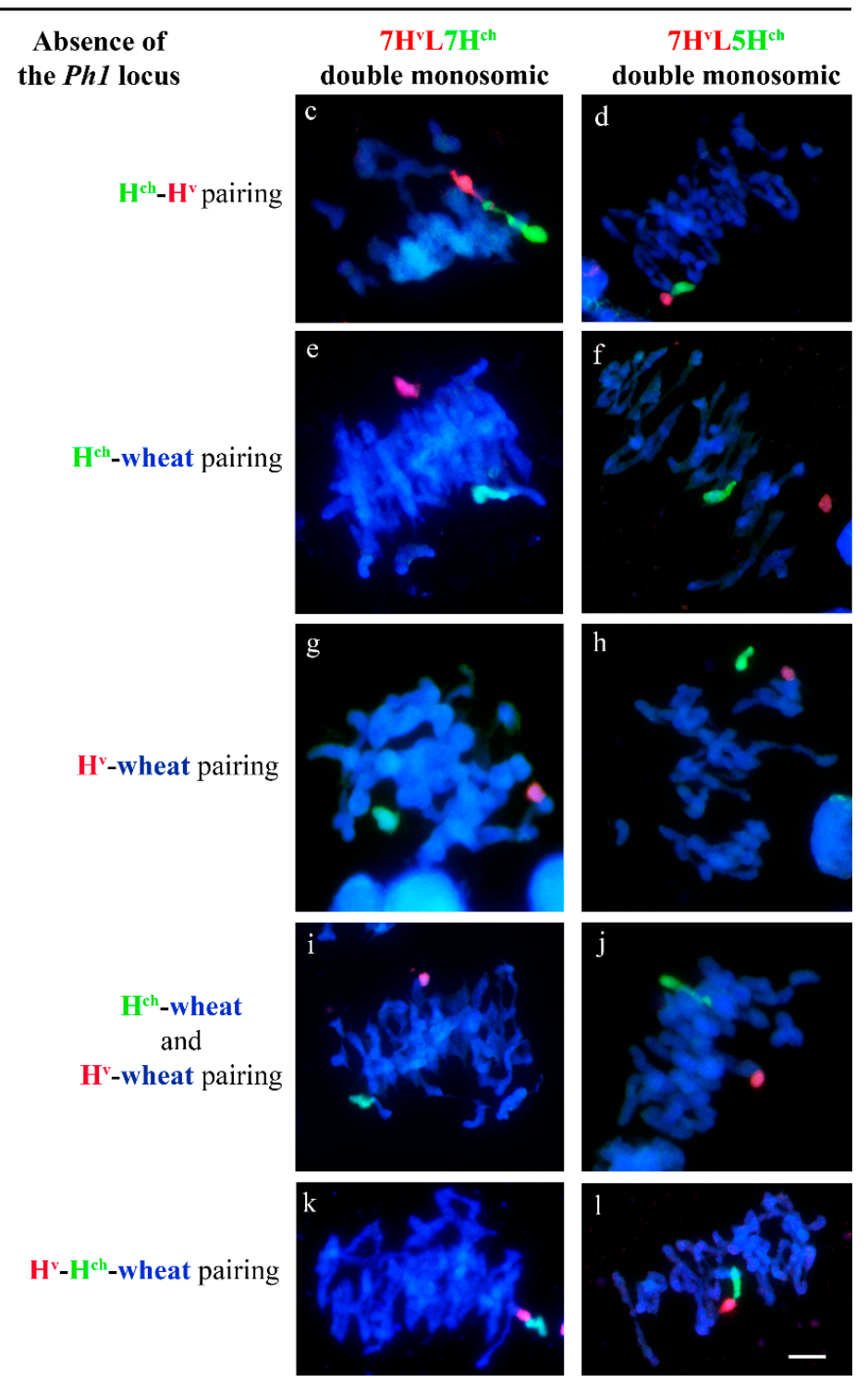

Figure 3. Interspecific chromosome associations during meiosis metaphase I between $H$. vulgare, $H$. chilense, and wheat in double monosomic addition lines in the presence and the absence of the Ph1 locus. Hordeum chilense and $H$. vulgare were visualized in green and red, respectively. DNA was counterstained with DAPI (blue). (a,b) $7 \mathrm{H}^{\mathrm{v}} 7 \mathrm{H}^{\mathrm{ch}}$ and $7 \mathrm{H}^{\mathrm{v}} 5 \mathrm{H}^{\mathrm{ch}}$ barley chromosomes did not associate in the presence of $P h 1$ locus. (c,d) $\mathrm{H}^{\mathrm{ch}}-\mathrm{H}^{\mathrm{v}}$ associations in both wheat lines in the $p h 1 b$ mutant background. (e,f) $\mathrm{H}^{\mathrm{ch}}$-wheat associations in the absence of the Ph1 locus. $(\mathbf{g}, \mathbf{h}) \mathrm{H}^{\mathrm{v}}$-wheat pairing in the absence of $P h 1$ locus. $(\mathbf{i}, \mathbf{j})$ Double $\mathrm{H}^{\mathrm{ch}}$-wheat and $\mathrm{H}^{\mathrm{v}}$-wheat pairing in wheat in the ph1b mutant background. (k,l) Tripartite chromosome associations in both lines in absence of the Ph1 locus. Bar: $10 \mu \mathrm{m}$. 
3.4. Segregation of the Inter-Specific Chromosome Associations Occurred Randomly in the Absence of the Ph1 Locus

Chromosome reorganizations in PMCs as the result of inter-specific chromosome associations were studied in later stages of meiosis in wheat only in the ph1b mutant background, since no recombination events were detected in the presence of the Ph1 locus. Almost 300 PMCs were screened in total in meiosis anaphase I using GISH. Several possible situations of inter-specific chromosome associations between $H$. chilense, $H$. vulgare, and wheat were identified in both lines carrying $7 \mathrm{H}^{\mathrm{v}} \mathrm{L} 7 \mathrm{H}^{\mathrm{ch}}$ and $7 \mathrm{H}^{\mathrm{v}} \mathrm{L} 5 \mathrm{H}^{\mathrm{ch}}$ chromosomes in wheat in the $p h 1 b$ mutant background (Figure 4). Hordeum chilense and H. vulgare chromosomes were usually observed to be delayed in the metaphase plate during anaphase I/telophase I, independently of being associated or unpaired (Figure 4). Hordeum chilense and $H$. vulgare chromosomes remained associated during anaphase I in the $7 \mathrm{H}^{\mathrm{v}} \mathrm{L} 7 \mathrm{H}^{\mathrm{ch}}$ double monosomic addition line in the $p h 1 b$ mutant background, but other chromosome associations between wheat and $H$. chilense or $H$. vulgare chromosomes were also visualized in anaphase I/telophase I, corresponding to previous chromosome associations observed in metaphase I (Figure $4 a-h)$. When chromosomes $7 \mathrm{H}^{\mathrm{v}} \mathrm{L}$ and $7 \mathrm{H}^{\mathrm{ch}}$ did not associate in metaphase I, both univalents segregated randomly, both in one cell, each one in each daughter cell or suffered chromosome misdivision (Figure 4i-k).
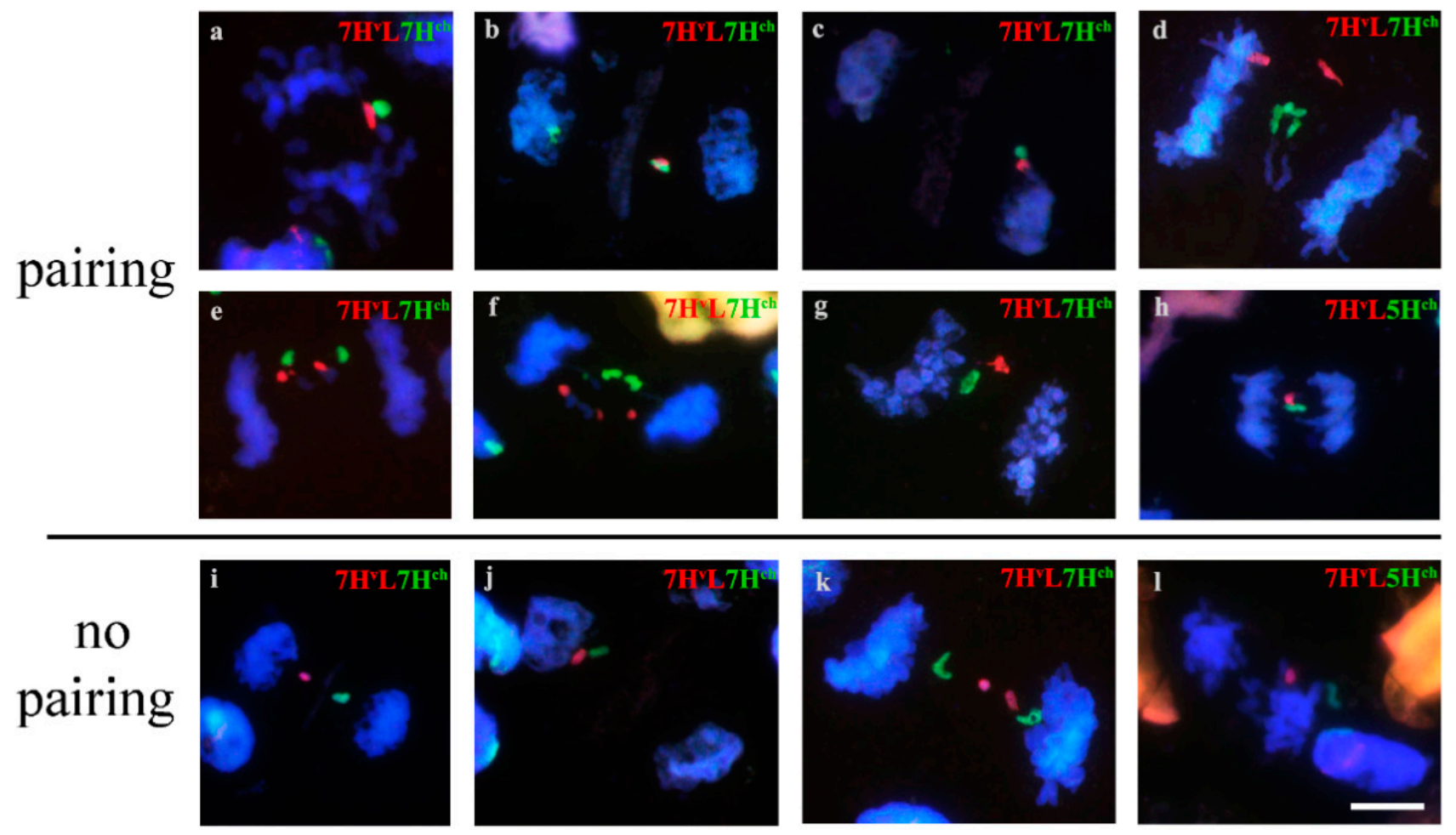

Figure 4. Chromosome segregation of barley chromosomes in double H. vulgare and H. chilense monosomic addition lines in wheat in the absence of the Ph1 locus. Examples of barley chromosome segregation are shown in both situations, whether barley chromosomes did crossover or not. Both barley chromosomes remain delayed in all situations. Hordeum vulgare and $H$. chilense chromosomes were visualised in red and green, respectively. DNA was counterstained.

Similarly, we visualized in anaphase I/telophase I interspecific chromosome associations between $H$. chilense and $H$. vulgare in the non-homoeologous $7 \mathrm{H}^{\mathrm{v}} \mathrm{L}^{2} \mathrm{H}^{\text {ch }}$ double monosomic addition line in the ph1b mutant background. We scored 150 PMCs by GISH and we observed chromosome associations between $H$. chilense and $H$. vulgare chromosomes in few cells corresponding with the low frequency of pairing previously visualized in metaphase I (Figure 4h), but we did not detect other chromosome associations such as $H$. vulgare-wheat, double $H$. chilense-wheat and $H$. vulgare-wheat, or the tripartite $H$. chilense- $H$. vulgare-wheat. As expected, non-homoeologous chromosome associations between $H$. 
chilense and $H$. vulgare were less frequent than $H$. chilense and $H$. vulgare associations for the same homoeologous group, corresponding to previous observations in pachytene and metaphase I (Table 2). Hordeum chilense and H. vulgare chromosomes segregated randomly when they did not associate previously in $7 \mathrm{H}^{\mathrm{v}} \mathrm{L} 5 \mathrm{H}^{\mathrm{ch}}$ double monosomic addition lines in the $p h 1 b$ mutant background (Figure 4l). Inter-specific chromosome associations were also visualized in tetrads, where several possibilities of $H$. chilense and $H$. vulgare segregation were detected, including the non-integration of the Hordeum chromosome, especially in the case of the H. vulgare $7 \mathrm{H}^{\mathrm{v}} \mathrm{L}$ chromosome (Figure 5).
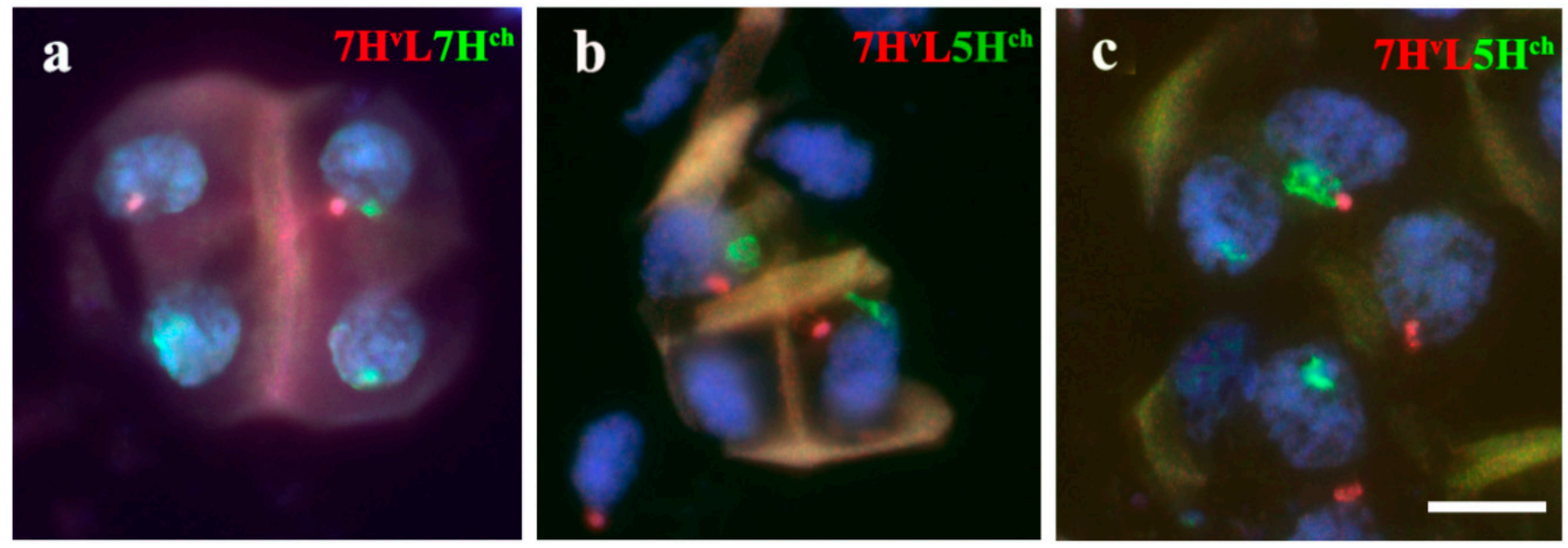

Figure 5. Visualization of barley chromosomes after meiosis in double H. vulgare and H. chilense monosomic addition lines in wheat in the absence of the Ph1 locus. Examples of both H. vulgare (red) and H. chilense (green) chromosomes at the tetrads stage. DNA was counterstained with DAPI (blue). (a) Hordeum vulgare and H. chilense chromatin detected in two and three PMCs, respectively, in the double monosomic $7 \mathrm{H}^{\mathrm{v}} \mathrm{L} 7 \mathrm{H}^{\mathrm{ch}}$ in wheat in the $p h 1 b$ mutant background. (b) $7 \mathrm{H}^{\mathrm{v}} \mathrm{L} 5 \mathrm{H}^{\mathrm{ch}}$ chromosomes detected simultaneously in two PMCs in wheat in the ph1b mutant background. (c) Hordeum vulgare and $H$. chilense chromatin detected in three and three PMCs, respectively, in the double monosomic $7 \mathrm{H}^{\mathrm{v}} \mathrm{L} 5 \mathrm{H}^{\mathrm{ch}}$ in wheat in the $p h 1 b$ mutant background. Bar: $10 \mu \mathrm{m}$.

Finally, it is worth mentioning that other chromosome rearrangements can occur during meiosis in the absence of the $P h 1$ locus. We detected one mosaic plant carrying the $7 \mathrm{H}^{\mathrm{v}} \mathrm{L} 5 \mathrm{H}^{\mathrm{ch}}$ chromosomes in the $p h 1 b$ mutant background. In situ hybridization in meiosis chromosome spreads of this plant revealed that both $H$. chilense and $H$. vulgare chromosomes were present only in some of the cell surrounding the meoicytes (Figure 6a,b). In fact, most of these cells and the meiocytes only carried the $H$. chilense chromosome, and just a few cells accompanying the meiocytes retained the $H$. vulgare chromosome. This observation suggested that a misdivision event occurred in an early mitosis event before meiosis, resulting in the loss of the H. vulgare chromosome in one cell, which later generated the meiocytes. This case of aneusomaty was only detected in anthers, as in somatic root cells, both $H$. chilense and $H$. vulgare chromosome were present in all cells (Figure 6c). Whether or not the Ph1 locus might be involved in this event remains to be elucidated. 

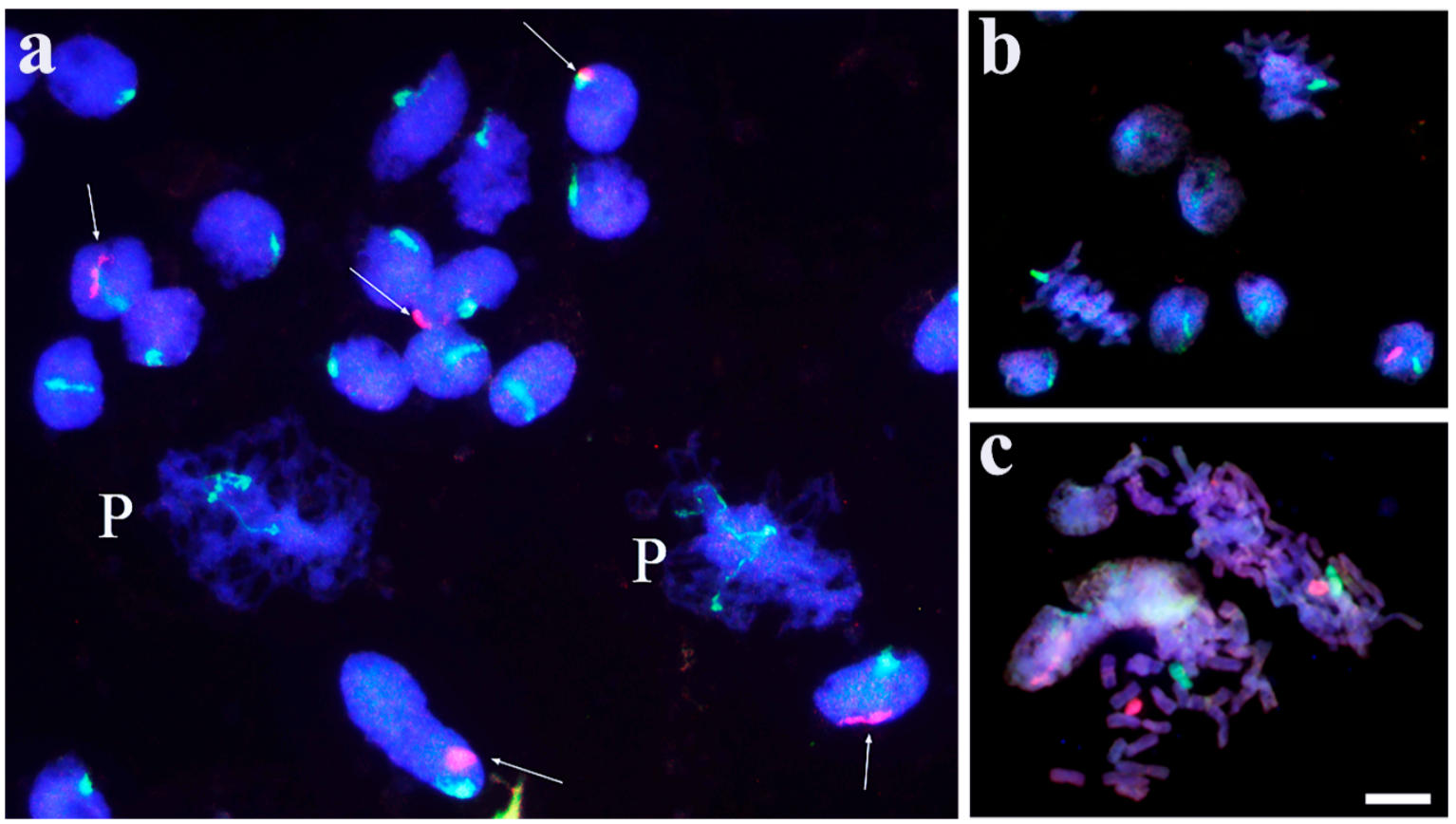

Figure 6. Mosaicism detected in the $7 \mathrm{H}^{\mathrm{v}} \mathrm{L} 5 \mathrm{H}^{\mathrm{ch}}$ double monosomic addition line in wheat in the absence of the Ph1 locus. Hordeum vulgare (red) and $H$. chilense (green) were visualised in meiotic $(\mathbf{a}, \mathbf{b})$ and somatic cells (c). DNA was counterstained with DAPI (blue). (a) Meiocytes in pachytene (P) showed only the H. chilense chromosome although somatic surrounding cells within the anther contained both H. vulgare and H. chilense chromosomes (arrowed). (b) Meiocytes in metaphase only showed the $H$. chilense chromosome. (c) Somatic cells from root tips in interphase and metaphase showed both barley chromosomes in all cells. Bar: $10 \mu \mathrm{m}$.

\section{Discussion}

Homologous chromosomes need to recognize each other to correctly associate, recombine and segregate. Plant breeders have always wished to transfer genetic variability from related species into a crop like wheat using genetic crosses, expecting recombination between chromosomes from the donor species and those from wheat. However, wheat genome has an enormous stability and recombination between non-homologous chromosomes is hampered. The genetic control of pairing and the physical divergence of the homoeologous genomes are considered the genetic systems responsible for the stable cytological diploid behavior of polyploid wheat [40,41]. The Ph1 locus has been described controlling correct pairing and suppressing homoeologous recombination in wheat $[19,24,42]$. In this work, to go deeper into the knowledge of the $P h 1$ locus function, we developed $H$. chilense and $H$. vulgare double monosomic addition lines in the wheat ph1b mutant background for the same and for different homoeology groups. For this, we used $H$. chilense and $\mathrm{H}$. vulgare monosomic addition lines for chromosomes $7 \mathrm{H}^{\mathrm{v}}, 5 \mathrm{H}^{\mathrm{ch}}$, and $7 \mathrm{H}^{\mathrm{ch}}$ in the wheat $p h 1 b$ mutant background developed previously [35] to be used as parental lines in genetic crosses. The wheat lines developed here in the absence of the Ph1 locus are equivalent to double monosomic addition lines for the same Hordeum chromosomes previously developed in our laboratory in the presence of the Ph1 locus [21]. However, we found difficulties in obtaining wheat lines carrying both Hordeum chromosomes intact at the same time in the ph1b mutant background. In fact, Hordeum vulgare chromosome 7 was always introgressed as a telochromosome $7 \mathrm{H}^{\mathrm{v}} \mathrm{L}$ and never the entire chromosome in the absence of the Ph1 locus. Chromosome misdivision by the centromere was frequently observed when univalents were present in the wheat background [43-45]. Particularly, $7 \mathrm{H}^{\mathrm{ch}}$ and $7 \mathrm{H}^{\mathrm{v}}$ telosomic chromosomes were found in wheat in the $p h 1 b$ mutant background in a higher frequency than the rest of the H. chilense and H. vulgare chromosomes [35]. This confirms the difficulties found in this work to retain the whole $7 \mathrm{H}^{\mathrm{v}}$ chromosome in the $H$. chilense and $H$. vulgare double monosomic addition lines in the absence of the Ph1 locus. 
Thus, chromosome association and recombination in the $p h 1 b$ mutant background was only possible to study between the long arm of chromosome $7 \mathrm{H}^{\mathrm{v}}$ and the long arm of both $7 \mathrm{H}^{\mathrm{ch}}$ (homoeologous) and $5 \mathrm{H}^{\text {ch }}$ (non-homoeologous) chromosomes.

Most of the studies performed during meiosis in wheat plants carrying alien chromosomes are focused on meiosis metaphase I or later stages [35,46,47]. Previously, we studied interspecific chromosome associations in early meiosis stages (pachytene) and we managed to track simultaneously extra wild and cultivated barley chromosomes (for the same and for different homoeology groups) in the wheat background using in situ hybridization [21]. Both wild and cultivated barley chromosomes were shown to be associated correctly in pairs in the presence of the Ph1 locus, suggesting that the Ph1 locus does not affect to specific chromosome associations [21]. In this work, our results confirmed these previous observations related to the effect of the $P h 1$ locus on homoeologous chromosome associations. Wild and cultivated barley homoeologous chromosomes can associate intimately either in the presence or in the absence of the Ph1 locus. In addition, we have clearly shown here that the $P h 1$ locus hampers crossing-overs between wild and cultivated barley homoeologous chromosomes in the absence of homologous chromosomes. Thus, crossing-overs between $H$. chilense and $H$. vulgare homoeologous chromosomes are only observed in the absence of the Ph1 locus. Crossovers between H. chilense and H. vulgare were previously detected in the $p h 1 b$ mutant background [33]. Previously, an increment on the crossover frequency between wheat homoeologous chromosomes was described in the $p h 1 b$ mutant background by targeting the MHL1 (a crucial component of the meiotic recombination machinery); sites that progressed to crossovers when environmental growing conditions were altered [48]. To the best of our knowledge, we have described here for the first time an increment of the crossovers and therefore recombination between both wild and cultivated barley species in the wheat background.

Other homoeologous chromosome associations have been previously described in the presence of $\mathrm{Ph}$ genes. For example, recombination between $H$. vulgare and $H$. bulbosum homoeologous chromosomes or between $5 \mathrm{M}^{\mathrm{g}}$ chromosome from Ae. geniculata and 5D chromosome were also observed in the wheat background [49,50]. Robertsonian translocations between $H$. chilense and $H$. vulgare were described before in the presence of the $P h 1$ locus [51]. However, different levels of allosyndesis between wheat chromosomes and $H$. vulgare and $H$. chilense or wheat and rye (Secale cereale) were detected in the ph1b mutant background $[33,52]$. Our results show that, although $H$. vulgare and $H$. chilense are phylogenetically quite distant [53], both species have a lot of similarities at the chromosomal level [54] allowing homoeologous chromosome associations and recombination between them in the absence of the Ph1 locus. Thus, our results also showed that the Ph1 locus suppresses recombination between homoeologous chromosomes as bivalents between homoeologous chromosomes were detected in metaphase I in the $p h 1 b$ mutant background.

Alterations in chromosome content can also be frequently generated by mistakes during cell division, producing aneuploidy or polyploidy progeny cells. It is not strange that high polyploids show a variable chromosome number even for the same ploidy level. This phenomenon was labelled as aneusomaty, referring to an intra-individual aneuploidy [55]. This term can be equivalent to mosaicism and in wheat can be assumed to arise as the result of the meiotic instability characteristic of freshly created allopolyploids [56]. In our work, we detected this aneusomaty or mosaicism phenomenon in one plant developed in the $p h 1 b$ mutant background carrying the $H$. chilense and $H$. vulgare non-homoeologous chromosomes. In our case, the H. vulgare chromosome was detected only in some somatic cells in the anther but in all somatic cells in the root tissue. Chromosome number variations in a population and at individual level can be frequent in high polyploids, especially in plants with an active vegetative reproduction [55,57-59]. This phenomenon has not been reported previously in the ph1b mutant background and more observations would be required to clarify whether or not the $P h 1$ locus might have an effect on it.

Subtelomeres are high polymorphic DNA structures, located near telomeres at the end of the chromosome arms [60], and include recombination hot spots [61,62]. This extraordi- 
nary polymorphism contributes to complicating the picture about the roles that subtelomeres play on chromosome associations and recombination during meiosis, although some studies in Arabidopsis and Hordeum species have shed some light on it [21,63-65]. In our work, crossovers were always observed at the distal region of the associated homoeologous chromosomes. Our results here also suggest that subtelomeres might play a function in the interspecific recombination between wild and barley chromosomes, as chiasmas are always located at the end of the chromosomes near the telomeres. The mechanism by which recombination at the subtelomeres between homoeologues is suppressed by the Ph1 locus remains to be elucidated.

Author Contributions: Both authors contributed to this manuscript. P.P. designed the research; P.P. and M.C.C. performed the experiments; P.P. and M.C.C. analyzed and discussed the results. All authors have read and agreed to the published version of the manuscript.

Funding: This research was supported by grants AGL2015-64833R and PDI2019-103339RB-100 from Spanish Ministerio de Economía y Competitividad and Ministerio de Ciencia e Innovación, respectively.

Acknowledgments: Authors deeply appreciate the comments from the independent reviewers during the revision of the manuscript.

Conflicts of Interest: The authors declare no conflict of interest.

\section{References}

1. Shewry, P.R. Wheat. J. Exp. Bot. 2009, 60, 1537-1553. [CrossRef]

2. Godfray, H.C.J.; Crute, I.R.; Haddad, L.; Lawrence, D.; Muir, J.F.; Nisbett, N.; Pretty, J.; Robinson, S.; Toulmin, C.; Whiteley, R. The future of the global food system. Philos. Trans. R. Soc. B Biol. Sci. 2010, 365, 2769-2777. [CrossRef] [PubMed]

3. O'Mara, J.G. The cytogenetics of Triticale. Bot. Rev. 1953, 19, 587-605. [CrossRef]

4. Martín, A.; Chapman, V. A hybrid between Hordeum chilense and Triticum aestivum. Cereal Res. Commun. 1977, 5, 365-368.

5. Lukaszewski, A.J. Manipulation of the 1RS.1BL Translocation in Wheat by Induced Homoeologous Recombination. Crop. Sci. 2000, 40, 216-225. [CrossRef]

6. Friebe, B.; Jiang, J.; Raupp, W.J.; McIntosh, R.A.; Gill, B.S. Characterization of wheat-alien translocations conferring resistance to diseases and pests: Current status. Euphytica 1996, 91, 59-87. [CrossRef]

7. Calderón, M.D.C.; Ramírez, M.D.C.; Martín, A.; Prieto, P. Development of Hordeum chilense 4 H ch introgression lines in durum wheat: A tool for breeders and complex trait analysis. Plant Breed. 2012, 131, 733-738. [CrossRef]

8. Rey-Santomé, M.D.; Calderón, M.-C.; Rodrigo, M.J.; Zacarías, L.; Alós, E.; Prieto, P. Novel Bread Wheat Lines Enriched in Carotenoids Carrying Hordeum chilense Chromosome Arms in the ph1b Background. PLoS ONE 2015, 10, e0134598. [CrossRef]

9. Bates, L.S.; DeYoe, C.W. Wide hybridization and cereal improvement. Econ. Bot. 1973, 27, 401-412. [CrossRef]

10. Martinez-Perez, E.; Shaw, P.; Moore, G. The Ph1 locus is needed to ensure specific somatic and meiotic centromere association. Nat. Cell Biol. 2001, 411, 204-207. [CrossRef]

11. Sears, E.R. Induced mutant with homoeologous pairing in common wheat. Can. J. Genet. Cytol. 1977, 19, 585-593. [CrossRef]

12. Mello-Sampayo, T. Genetic Regulation of Meiotic Chromosome Pairing by Chromosome 3D of Triticum aestivum. Nat. New Biol. 1971, 230, 22-23. [CrossRef] [PubMed]

13. Driscoll, C.J. Genetic suppression of homoeologous chromosome pairing in hexaploid wheat. Can. J. Genet. Cytol. 1972, 14, 39-42. [CrossRef]

14. Prieto, P.; Moore, G.; Reader, S. Control of conformation changes associated with homologue recognition during meiosis. Theor. Appl. Genet. 2005, 111, 505-510. [CrossRef] [PubMed]

15. Okamoto, M. A synaptic effect of chromosome V. Wheat Inf. Serv. 1957, 5, 6. Available online: http://ci.nii.ac.jp/naid/1002971082 4/en/ (accessed on 15 July 2020).

16. Riley, R.; Chapman, V. Genetic Control of the Cytologically Diploid Behaviour of Hexaploid Wheat. Nat. Cell Biol. 2006, 182, 713-715. [CrossRef]

17. Sears, E.R.; Okamoto, M. Intergenomic chromosome relationship in hexaploid wheat. In Proceedings of the 10th Inter-national Congress of Genetics, Toronto, ON, Canada, 20-27 August 1958; pp. 258-259.

18. Moore, G. The Control of Recombination in Wheat by Ph1 and Its Use in Breeding. In Advanced Structural Safety Studies; Springer Science and Business Media LLC: Berlin/Heidelberg, Germany, 2014; Volume 1145, pp. 143-153.

19. Martín, A.C.; Rey, M.-D.; Shaw, P.; Moore, G. Dual effect of the wheat Ph1 locus on chromosome synapsis and crossover. Chromosoma 2017, 126, 669-680. [CrossRef]

20. Rey, M.-D.; Martín, A.C.; Higgins, J.; Swarbreck, D.; Uauy, C.; Shaw, P.; Moore, G. Exploiting the ZIP4 homologue within the wheat Ph1 locus has identified two lines exhibiting homoeologous crossover in wheat-wild relative hybrids. Mol. Breed. 2017, 37, 1-11. [CrossRef] 
21. Calderón, M.C.; Rey, M.-D.; Martín, A.; Prieto, P. Homoeologous Chromosomes from Two Hordeum Species Can Recognize and Associate During Meiosis in Wheat in the Presence of the Ph1 Locus. Front. Plant Sci. 2018, 9, 585. [CrossRef]

22. Jenczewski, E.; Alix, K. From Diploids to Allopolyploids: The Emergence of Efficient Pairing Control Genes in Plants. Crit. Rev. Plant Sci. 2004, 23, 21-45. [CrossRef]

23. Pawlowski, W.P. Chromosome organization and dynamics in plants. Curr. Opin. Plant Biol. 2010, 13, 640-645. [CrossRef] [PubMed]

24. Prieto, P.; Shaw, P.; Moore, G. Homologue recognition during meiosis is associated with a change in chromatin conformation. Nat. Cell Biol. 2004, 6, 906-908. [CrossRef]

25. Naranjo, T.; Corredor, E. Nuclear architecture and chromosome dynamics in the search of the pairing partner in meiosis in plants. Cytogenet. Genome Res. 2008, 120, 320-330. [CrossRef]

26. Naranjo, T. The Effect of Chromosome Structure upon Meiotic Homologous and Homoeologous Recombinations in Triticeae. Agronomy 2019, 9, 552. [CrossRef]

27. Greer, E.; Martín, A.C.; Pendle, A.; Colas, I.; Jones, A.M.; Moore, G.; Shaw, P. The Ph1 Locus Suppresses Cdk2-Type Activity during Premeiosis and Meiosis in Wheat. Plant Cell 2012, 24, 152-162. [CrossRef] [PubMed]

28. Chang, S.-B.; De Jong, H. Production of alien chromosome additions and their utility in plant genetics. Cytogenet. Genome Res. 2005, 109, 335-343. [CrossRef] [PubMed]

29. Miller, T.E.; Reader, S.M.; Chapman, V. The Addition of Hordeum Chilense Chromosomes to Wheat. In Induced Variability in Plant Breeding: Proceedings of an International Eucarpia Symposium; Wageningen Academic Publishers: Wageningen, The Netherlands, 1982; pp. 79-81.

30. Islam, A.K.M.R.; Shepherd, K.W.; Sparrow, D.H.B. Production and characterization of wheat-barley addition lines. In Proceedings of the 5th International Wheat Genetics Symposium, New Delhi, India, 23-28 February 1978; pp. 365-371.

31. Islam, A.K.M.R.; Shepherd, K.W.; Sparrow, D.H.B. Isolation and characterization of euplasmic wheat-barley chromosome addition lines. Heredity 1981, 46, 161-174. [CrossRef]

32. Maestra, B.; De Jong, J.H.; Shepherd, K.; Naranjo, T. Chromosome arrangement and behaviour of two rye homologous telosomes at the onset of meiosis in disomic wheat-5RL addition lines with and without the Ph1 locus. Chromosom. Res. 2002, 10, 655-667. [CrossRef]

33. Rey, M.-D.; Calderon, M.C.; Prieto, P. The use of the ph1b mutant to induce recombination between the chromosomes of wheat and barley. Front. Plant Sci. 2015, 6, 160. [CrossRef]

34. Murray, M.; Thompson, W. Rapid isolation of high molecular weight plant DNA. Nucleic Acids Res. 1980, 8, 4321-4326. [CrossRef]

35. Hernández, P.; Dorado, G.; Prieto, P.; Giménez, M.J.; Ramírez, M.C.; Laurie, D.A.; Snape, J.W.; Martín, A. A core genetic map of Hordeum chilense and comparisons with maps of barley (Hordeum vulgare) and wheat (Triticum aestivum). Theor. Appl. Genet. 2001, 102, 1259-1264. [CrossRef]

36. Wang, X.; Lai, J.; Liu, G.; Chen, F. Development of a scar marker for the Ph1 Locus in common wheat and its application. Crop. Sci. 2002, 42, 1365-1368. [CrossRef]

37. Liu, Z.; Biyashev, R.M.; Maroof, M.S. Development of simple sequence repeat DNA markers and their integration into a barley linkage map. Theor. Appl. Genet. 1996, 93, 869-876. [CrossRef] [PubMed]

38. Hagras, A.A.-A.; Kishii, M.; Tanaka, H.; Sato, K.; Tsujimoto, H. Genomic differentiation of Hordeum chilense from H. vulgare as revealed by repetitive and EST sequences. Genes Genet. Syst. 2005, 80, 147-159. [CrossRef] [PubMed]

39. Prieto, P.; Martin, A.; Cabrera, A.; Soliman, M.H. Chromosomal distribution of telomeric and telomeric-associated sequences in Hordeum chilense by in situ hybridization. Heredity 2004, 141, 122-127. [CrossRef] [PubMed]

40. Feldman, M.; Levy, A.A. Genome Evolution Due to Allopolyploidization in Wheat. Genetics 2012, 192, 763-774. [CrossRef]

41. Leitch, A.R.; Bennett, M.D. Polyploidy in angiosperms. Trends Plant Sci. 1997, 2, 470-476. [CrossRef]

42. Mello-Sampayo, T.; Canas, A.P. Suppressors of meiotic chromosome pairing in common wheat. In Proceedings of the 4th International Wheat Genetics Symposium; Sears, E.R., Sears, L.M.S., Eds.; Columbia University of Agricultural Experiment Station, College of Agriculture, and Missouri: Columbia, MO, USA, 1973; pp. 703-713.

43. Sears, E.-R. Misdivision of univalents in common wheat. Chromosoma 1950, 4, 535-550. [CrossRef]

44. Steinitz-Sears, L.M. Somatic Instability of Telocentric Chromosomes in Wheat and the Nature of the Centromere. Genetics 1966, 54, 241-248. [CrossRef]

45. Friebe, B.; Zhang, P.; Linc, G.; Gill, B. Robertsonian translocations in wheat arise by centric misdivision of univalents at anaphase I and rejoining of broken centromeres during interkinesis of meiosis II. Cytogenet. Genome Res. 2005, 109, 293-297. [CrossRef]

46. Molnár-Láng, M.; Linc, G.; Logojan, A.; Sutka, J. Production and meiotic pairing behaviour of new hybrids of winter wheat (Triticum aestivum) $\times$ winter barley (Hordeum vulgare). Genome 2000, 43, 1045-1054. [CrossRef]

47. Silkova, O.G.; Kabanenko, Y.N.; Loginova, D.V. The effect of wheat-rye substitution on chromosome elimination: An analysis of univalents' behavior in wheat meiosis with dimonosomy and tetramonosomy. Russ. J. Genet. 2014, 50, 245-252. [CrossRef]

48. Martín, A.C.; Shaw, P.; Phillips, D.W.; Reader, S.; Moore, G. Licensing MLH1 sites for crossover during meiosis. Nat. Commun. 2014, 5, 4580. [CrossRef] [PubMed]

49. Zhang, L.; Pickering, R.; Murray, B.G. Direct measurement of recombination frequency in interspecific hybrids between Hordeum vulgare and H. bulbosum using genomic in situ hybridization. Heredity 1999, 83, 304-309. [CrossRef] [PubMed] 
50. Liu, W.; Rouse, M.; Friebe, B.; Jin, Y.; Gill, B.; Pumphrey, M.O. Discovery and molecular mapping of a new gene conferring resistance to stem rust, Sr53, derived from Aegilops geniculata and characterization of spontaneous translocation stocks with reduced alien chromatin. Chromosom. Res. 2011, 19, 669-682. [CrossRef] [PubMed]

51. Prieto, P.; Ramíarez, M.C.; Ballesteros, J.; Soliman, M.H. Identification of Intergenomic Translocations Involving Wheat, Hordeum Vulgare and Hordeum Chilense Chromosomes by FISH. Heredity 2004, 135, 171-174. [CrossRef]

52. Miller, T.E.; Reader, S.M.; Purdie, K.A.; King, I.P. Determination of the frequency of wheat-rye chromosome pairing in wheat $x$ rye hybrids with and without chromosome 5B. Theor. Appl. Genet. 1994, 89, 255-258. [CrossRef]

53. Blattner, F.R. Progress in phylogenetic analysis and a new infrageneric classification of the barley genus Hordeum (Poaceae: Triticeae). Breed. Sci. 2009, 59, 471-480. [CrossRef]

54. Aliyeva-Schnorr, L.; Stein, N.; Houben, A. Collinearity of homoeologous group 3 chromosomes in the genus Hordeum and Secale cereale as revealed by $3 \mathrm{H}$-derived FISH analysis. Chromosom. Res. 2016, 24, 231-242. [CrossRef]

55. Duncan, R.E. Production of variable aneuploid numbers of chromosomes within the root tips of Parphiopedilum wardiiSummerhayes. Am. J. Bot. 1945, 32, 506-509. [CrossRef]

56. Luo, J.; Zhao, L.; Zheng, J.; Li, Y.; Zhang, L.; Liu, D.; Pu, Z.; Hao, M. Karyotype mosaicism in early generation synthetic hexaploid wheats. Genome 2020, 63, 329-336. [CrossRef] [PubMed]

57. Lewis, W.H. Chromosomal Drift, a New Phenomenon in Plants. Science 1970, 168, 1115-1116. [CrossRef] [PubMed]

58. Persson, K. Biosystematic studies in the Artemisia maritimacomplex in Europe. Opera Bot. 1974, 35, 1-188.

59. Couderc, H.; Gorenflot, R.; Calame, F.G.; Küpfer, P. La polyploïdie chez les plantes. Bot. Helv. 1980, 108, 5-37.

60. Samonte, R.V. Structural Dynamics of Eukaryotic Chromosome Evolution. Science 2003, 301, 793-797. [CrossRef]

61. Linardopoulou, E.V.; Williams, E.M.; Fan, Y.; Friedman, C.; Young, J.M.; Trask, B.J. Human subtelomeres are hot spots of interchromosomal recombination and segmental duplication. Nat. Cell Biol. 2005, 437, 94-100. [CrossRef]

62. Aguilar, M.; Prieto, P. Sequence analysis of wheat subtelomeres reveals a high polymorphism among homoeologous chromosomes. Plant Genome 2020, 13, e20065. [CrossRef]

63. Kotani, H.; Hosouchi, T.; Tsuruoka, H. Structural Analysis and Complete Physical Map of Arabidopsis thaliana Chromosome 5 Including Centromeric and Telomeric Regions. DNA Res. 1999, 6, 381-386. [CrossRef]

64. Heacock, M.; Spangler, E.; Riha, K.; Puizina, J.; Shippen, D.E. Molecular analysis of telomere fusions in Arabidopsis: Multiple pathways for chromosome end-joining. EMBO J. 2004, 23, 2304-2313. [CrossRef]

65. Calderón, M.D.C.; Rey, M.-D.; Soliman, M.H.; Prieto, P. The subtelomeric region is important for chromosome recognition and pairing during meiosis. Sci. Rep. 2014, 4, 6488. [CrossRef] 